\title{
Awareness and Perspective of Internet Banking in Kanyakumari District
}

\author{
M.P.Santhiya, R.Radhika
}

\begin{abstract}
The major change witnessed in the banking sector had made a wide advances in financial motivation and technology, which resultant to global financial environment. The improvement in technology and financial innovation gave birth to a new concept known as Internet banking and it was become an intense part of banking sector. This internet banking has made a revolutionary change in the lives of all the individuals, means technology changing client habits in banking business. Internet banking has become a major part of the financial environment in order to meets the requirements of the customers and banking sectors. The study makes an attempt to study the concept and awareness on the impact of internet banking on the customers of SBI in kanyakumari district.
\end{abstract}

Keywords-Internet banking, e banking services.

\section{INTRODUCTION}

Internet banking system is developed in order to help the clients to perform their day to day transactions. by Internet banking clients can perform their banking activities by sitting at home .internet banking is also known as online banking, the system allows both transactional and non transactional features. Thus the concept of Internet banking had made a revolution in the field of banking and finance.

\section{Internet banking at SBI:}

On 2001K,laterMPG appointed consultant for preparing IT plans to he banks later core banking system is proposed by the IT company .on 2002 all the banks were computerized and core banking system had took place, by 2008 more than 6500 branches on core banking system. At last the term Internet banking facility for customers were launched on 2008 ,followed with more interfaces with ecommerce and other channels like ATM, Online banking etc.

Services provided by SBI (Internet Banking) :

- Online SBI

- Retail banking

$\checkmark$ issue of demand draft online

$\checkmark$ Transfer funds

$\checkmark$ Generate account statements

$\checkmark$ E-Tax for online tax payment

$\checkmark$ E-pay for automatic bill payment.

- Corporate banking

- Value added services

- Products and services

Revised Manuscript Received on October 25, 2019.

M.P.Santhiya, Department of MBA, Noorul Islam Centre for Higher Education, Kumaracoil, Kanya kumari District. Tamilnadu, India,Email: sandyamadhavan@gmail.com

R.Radhika, Department of MBA,Noorul Islam Centre for Higher Education, Kumaracoil,Thuckalay, T.N

Corresponding Email: rdhujaasourish@gmail.com
$>$ RTGS/NEFT

$>$ SBI E- Tax

$>$ E-Ticketing

$>$ Demand Draft

$>$ Account statement

$>$ Balance Enquiry

$>$ Account opening request

$>$ Transaction Enquiry

$>$ Cheque Book request

\section{LITERATURE REVIEW}

In [1] highlights the challenges faced by the Indian banks in adoption of Internet banking technology. E banking has gained an important part in the Indian context ,many of the banks have implemented the E banking facilities which is beneficial to the banks and the customers. Even though there was many challenges in the implementation of $\mathrm{E}$ banking technology in India but at the same time E banking is having a bright future. Atm, Debit and credit cards has become a good source of usage of IT has paved a way to digitalization.

In [2] The researcher highlighted the challenges of adopting the use of e banking among the customers, at the end of the investigation it is to be found that security is not an challenge in adoption of e banking, education qualification and the cost associated with internet banking is the significant challenge for adopting and use e banking among the customers. So the banks concentrate on the benefits, costs, and to create a awareness part towards the customers and the merchants. The use of e banking is beneficial to both banks and the customers ,because the customers believes the service reduces their transaction time.

In [3] examined the customers perception towards online banking. The study found that majority of the customers are not aware about the term online banking. customers from the rural areas are facing various problems by the usage of online banking such as lack of awareness, no proper guidance, fear on personal information. proper development of infrastructure facility, popularization of banking products, safety and security are the suggestions given by the researcher to resolve the problem. Online banking has great facility for customers, but many people have lack of awareness towards the technology. So banks should spend fund and time to their customers would be beneficial than the inclusive growth will be high in rural india.

In[4] highlights the E banking challenges and opportunities lies in the banking industry. The article defined some of the problems faced by the developing countries which have low penetration of information and telecommunication Technology .lacking in realizing the technology initiatives, major concern about the digital divide between the different operational

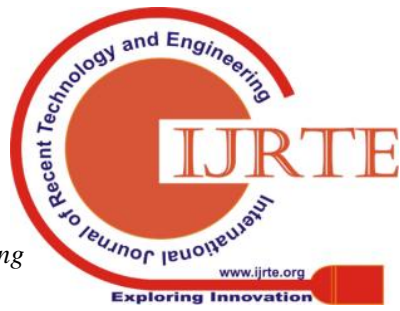




\section{Awareness and Perspective of Internet Banking in Kanyakumari District}

environments of public and private sector banks. problem of security and inadequate financing of small and medium scale enterprises are highlighted.

In[5]article discuss the importance, problems faced by the technology and the ways to over come the problems. It is recognized that online banking provides cost less per transaction than any other channel, including phone banking. The customers naturally navigate to the technology which is very easy to use and offer the best service. Banks aims to improve the profits more from the adoption of the technology.

\section{PROBLEM STATEMENT}

By the entry of the foreign banks the indian banks are facing a huge problem. since the market is competitive ,the use of modern technology in the process of banking service is necessary and essential. now a days the requirements of the customers are expanding very fast. The success of the banks depends up on fulfilling the customers needs. Therefore, the bank should be customer oriented to meet challenges of today's competitive environment. Therefore this research made an attempt to study the awareness and customers perspective towards Internet banking.

\section{OBJECTIVE OF THE STUDY}

1. To find out the awareness on the impact of benefit of Internet banking.

2. To find the factors that affects the customers in adoption of Internet banking technology.

\section{RESEARCH METHODOLOGY}

\section{A. Survey design}

The survey instrument was designed and used for data collection for this study. This study used both primary and secondary data. Secondary data were collected from thesis, websites, various journals and books. Primary data is collected through structured questionnaire

\section{B. Data Collection}

Data were collected from 150 respondents who are all holding a bank account in SBI .

\section{DATA ANALYSIS AND HYPOTHESIS TESTING}

\section{Tools for Analysis :}

The following statistical tools have been used for the purpose of analyzing data collected.

\section{* Percentage analysis \\ * T-test \\ * ANOVA}

\section{Percentage Analysis :}

Table 1: Demographic profile of the Respondents

\begin{tabular}{|l|l|r|r|}
\hline Variables & Parameters & frequency & Percentage \\
\hline Genders & Male & 103 & 68.7 \\
\cline { 2 - 4 } & Female & 47 & 31.3 \\
\cline { 2 - 4 } & Total & 150 & 100.0 \\
\hline \multirow{4}{*}{ Age } & Below 30 & 42 & 28.0 \\
\cline { 2 - 4 } & $30-40$ & 71 & 47.3 \\
\cline { 2 - 4 } & Above 40 & 37 & 24.7 \\
\cline { 2 - 4 } & Total & 150 & 100.0 \\
\hline Educational & Up to HSC & 19 & 12.7 \\
\hline
\end{tabular}

\begin{tabular}{|l|l|r|r|}
\hline qualification & UG & 41 & 27.3 \\
\cline { 2 - 4 } & PG & 90 & 60.0 \\
\cline { 2 - 4 } & Total & 150 & 100.0 \\
\hline Occupation & Employee & 92 & 61.3 \\
\cline { 2 - 4 } & Business & 37 & 24.7 \\
\cline { 2 - 4 } & Housewife & 21 & 14.0 \\
\cline { 2 - 4 } & Total & 150 & 100.0 \\
\hline Marital status & Married & 126 & 84.0 \\
\cline { 2 - 4 } & Unmarried & 24 & 16.0 \\
\cline { 2 - 4 } & Total & 150 & 100.0 \\
\hline
\end{tabular}

Source: Primary Data

It is observed from the above table that majority of the respondents are belong to Male category, most of them are the age group of 30-40years.Educational qualification of most of the respondents are at to PG degree level, majority of the respondents are employees and most of the respondents are married

2. T-test :

Hypothesis I:There is no significant relationship between the gender with respect to the impact of Internet banking practices.

Table 2:t-test for significant relationship between Gender with respect to impact factors

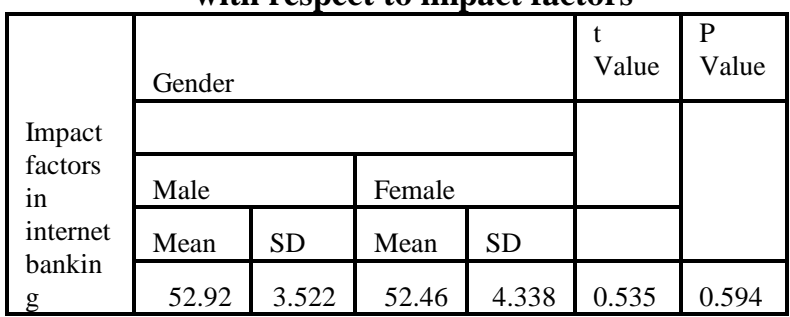

Source: Primary Data

Since the $\mathrm{P}$ value is greater than 0.05 . Hence the null hypothesis is accepted at $5 \%$ level with respect to the impact of internet banking practices. so we can conclude that there is no significance relationship between gender with respect to the impact of internet banking practices.

Hypothesis II : There is no significant relationship between Martial status with respect to the impact of Internet banking practices.

Table 3:t-test for significant relationship between Martial status with respect to the impact factors

\begin{tabular}{|c|c|c|c|c|c|}
\hline \multirow{2}{*}{$\begin{array}{l}\text { Factors } \\
\text { in } \\
\text { Internet } \\
\text { bankin } \\
\mathrm{g}\end{array}$} & \multicolumn{3}{|c|}{ Education Qualification } & \multirow[t]{2}{*}{$\mathrm{F}$ value } & \multirow{2}{*}{$\begin{array}{l}\mathrm{P} \\
\text { value }\end{array}$} \\
\hline & $\begin{array}{l}\text { Upto } \\
\text { HSc }\end{array}$ & UG & PG & & \\
\hline & $\begin{array}{r}25.00 \\
(5.774 \\
)\end{array}$ & $\begin{array}{r}25.17 \\
(6.336)\end{array}$ & $\begin{array}{r}26.67 \\
(5.872 \\
)\end{array}$ & .655 & 0.522 \\
\hline
\end{tabular}

\section{Source: Primary Data}

Since the $\mathrm{P}$ value is greater than 0.05 . Hence the null hypothesis is accepted at $5 \%$ level with respect to the impact factor of internet banking. so we can conclude that there is no significance difference between Marital status with respect to the impact of Internet banking practices.

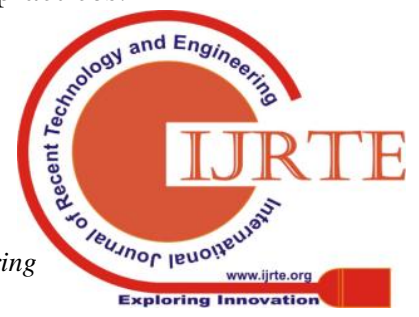




\section{ANOVA :}

Hypothesis III : There is no significant relationship between age group with respect to factors affects in adoption of Internet banking

Table 4:ANOVA for significance difference among age group with respect to factors affects in adoption of Internet banking

\begin{tabular}{|l|l|l|l|l|l|l|}
\hline \multirow{4}{*}{$\begin{array}{l}\text { Impact } \\
\text { factors }\end{array}$} & \multicolumn{3}{|c|}{ Marital status } & \multicolumn{1}{|c|}{$\begin{array}{l}\text { value } \\
\text { in }\end{array}$} & \multicolumn{3}{|c|}{\begin{tabular}{l} 
value \\
\cline { 2 - 5 } $\begin{array}{l}\text { internet } \\
\text { banking }\end{array}$
\end{tabular}} & married & unmarried & & \\
\cline { 2 - 5 } & 52.9 & 3.853 & 52.45 & 3.334 & 0.49 & 0.626 \\
\hline
\end{tabular}

Source: Primary Data

Since the $\mathrm{P}$ value is greater than 0.05 .Hence the null hypothesis is accepted at 5\%level with regard to the factors affects in the adoption of Internet banking. so we can conclude that there is no significance difference between the age group with respect to factors affects in adoption of Internet banking

Hypothesis IV : There is no significant relationship between Education qualification with respect to factors affects in adoption of Internet banking

Table 5:ANOVA for significance difference among between Education qualification with respect to factors affects in adoption of Internet banking

\begin{tabular}{|c|c|c|c|c|c|}
\hline \multirow{3}{*}{$\begin{array}{l}\text { Factors } \\
\text { in } \\
\text { Internet } \\
\text { bankin } \\
\mathrm{g}\end{array}$} & \multicolumn{3}{|c|}{ Age Group } & \multirow[t]{2}{*}{$F$ value } & \multirow[t]{2}{*}{$P$ value } \\
\hline & $\begin{array}{l}\text { Below } \\
30\end{array}$ & $30-40$ & $\begin{array}{l}\text { Above } \\
40\end{array}$ & & \\
\hline & $\begin{array}{l}25.83 \\
-6.531\end{array}$ & $\begin{array}{l}25.92 \\
-5.725\end{array}$ & $\begin{array}{l}28.83 \\
-4.877\end{array}$ & 1.301 & 0.277 \\
\hline
\end{tabular}

Source: Primary Data

Since the $\mathrm{P}$ value is greater than 0.05 .Hence the null hypothesis is accepted at 5\%level with regard to the factors affects in the adoption of Internet banking. so we can conclude that there is no significance difference between the education qualification with respect to factors affects in adoption of Internet banking

\section{FINDINGS}

From the Demographic profile of the customers it is to be found that majority of the customers are male, majority of the respondents are falls between the age group of 30-40 years. On education qualification most of the respondents are at PG level. For impact factors analysis from hypothesis I and II the null hypothesis is accepted which indiactes that there is no relationship between the impact of Internet banking with Gender and age group and for problem analysis Hypothesis III and IV are accepted at 5\% level which initiates there is no relationship between

\section{SUGGESTIONS}

- The banks should strengthen their security measures to control frauds for customer safety .

- Bank should provide proper awareness to their customers about the usage of the technology by conducting awareness camps, customer care centers, etc. communication can be given through press, media, by constructing websites etc.

- Transaction cost regarding internet banking should be minimized or eliminated if it is possible, this may leads more customers to opt the technology.

\section{CONCLUSION}

Therefore this study identifies the awareness level and problem among the customers in adoption of internet banking technology. Internet banking is a great boon to the customers. All most all the banking transactions except withdrawals and deposits done through internet banking. So banks need to educate the customers that they are not technologically strong. Finally the concludes that e-banking is need of hour even though it has hurdels in its implementation process but at the same time it has a bright future in India.

\section{REFERENCES}

1. Nitsure R.R "E banking: Challenges \&opportunities", Economic and weekly, vol.38 pp.5377-5381

2. Saviour Lusaya \&Bornwell Kalumba,"The challenges of adopting the use of $\mathrm{E}$ banking to the customers:The case of kasama district banking customers,scholar journal of applied science \&research,vol 1:2,2018,pp. 26-30

3. Dr A.Rajanna, "Perception of rural customers towards online banking: A case study "International journal of academic research and development",vol.2,2017,pp 87-93

4. Ameena Farooqui and $\mathrm{P}$ Rajani,"E Banking issues and challenges",IOSR journal of business management,vol. 19,2017,pp 31-39

5. Anthony,"User friendly E-Banking:A survey of online E banking retail initiatives",Communication of the ACM,vol.47,2004, pp 99-102

6. Mansour Naser Atraja and Badreldin F.Salim," The Adoption of Internet banking:clients perspective in oman International review of Management and marketing,vol.6,2016,pp 926-929

7. Sweety Gupta,Anshu Yadav,"The impact of Electronic banking and information Technology on the employees of banking sector"SAGE journals of management \&Labour studies,vol.10,2017,pp 1-5

8. Gob Mei Ling \& Yeo sook ferm,"Understanding customer satisfaction of internet banking:A case study in Malacca".fifth International conference of Marketing and retailing,2015,pp.80-85

9. Abdullah Binomar, "customer perception towards online banking services:empirical evidence from pakistan" journal of internet banking and commerce,vol.16,2011,pp 1-24

10. Rajni sinha,"A study on E banking services:its risks \&impacts",journal of business management \&social sciences research,vol.5,2016,pp 200-206 